\title{
Denial attitude and behavior as a response to the COVID-19 pandemic: A qualitative study
}

\author{
Sabiqotul Husna \\ Psychology Department, Universitas Islam Negeri Sunan Kalijaga, Indonesia \\ Corresponding author: sabiqotul.husna@uin-suka.ac.id
}

\section{ARTICLE INFO}

Article history

Received December 26, 2020

Revised July 31, 2021

Accepted August 1, 2021

Keywords

attitude;

behavior;

COVID-19;

denial;

pandemic.

\begin{abstract}
Amid various reactions and public responses to the uncertain situation and changes during the COVID-19 pandemic, some groups and individuals worldwide expressed denial attitudes and behavior, including in Indonesia. This paper aimed to explore denial attitude and behavior, particularly on social learning and observational learning theory. A qualitative survey method with open-ended questions was applied to gather data from 15 individuals who believed the COVID-19 pandemic was part of conspiracy theory and or does not exist. The results show a social learning process leads to the occurrence of attitudes and behaviors that deny the current existence of the COVID-19. Observational learning with a reference group strengthens individuals adapting and forming behavior similar to their reference group. Believing conspiracy theory and having negative perception and behavior towards medical workers are types and characteristics of attitude and behaviors in denying the COVID19 pandemic. The denial attitude and behavior can ultimately be concluded as a psychosocial response that emerged due to social learning and individual factors, including insufficient access to reliable information and conspiracy theories that were received massively from social media and broadcast message groups. These findings suggest that more attention needs to be given to social and individual factors as causes of the COVID-19 pandemic denial.
\end{abstract}

\section{Introduction}

The current COVID-19 pandemic has brought various consequences and complex social dynamics. As a result, economic recession and the downfall of the healthcare system occur in all countries, including Indonesia (Mahendradhata et al., 2021; Utami \& Aliyansah, 2020). In the global context, the scale of the COVID-19 pandemic impact was classified as unprecedented. Research suggested it may take more than a decade for the world to recover socially and economically from this pandemic (Djalante et al., 2020).

More specifically, in Indonesia, the COVID-19 pandemic mitigation carried out by the Indonesian government was considered unsuccessful. The government response was slow and did not consider the impact of the outbreak from the beginning. The impression of throw-off responsibilities between government agencies was also felt during the pandemic. Regional head officers tend to act alone and create the impression of Central-Regional dissimilarity. The Central Government, which should have been preventive, basically took actions that were considered unresponsive (Fadhal, 2020). In addition, the government has made many blunders or mistakes in managing and conveying information, particularly the 
misalignment of statements declared by high state officials (Widaningrum \& Mas'udi, 2020). Furthermore, a country is categorized as unresponsive or low responsiveness when it underestimates the urgency of handling and the impact of a pandemic at the beginning of a crisis (Mas'udi \& Winanti, 2020). During the second wave in July 2021, the Indonesian government has also decided to re-impose the restriction policy to slow down the increased number of COVID-19 cases (Paramadhita, 2021). In July 2021, Indonesia has recorded 3.082.410 confirmed positive cases of COVID-19 and 80.598 deaths (WHO, 2020). This data was in line with the data from the Indonesian government that in July 2021, Indonesia had 3.127.826 confirmed positive cases, with the death of 82.013 people, 574.135 patients in care, 2.471.678 of patient recovery (Kawalcovid19, 2020).

Some groups and individuals expressed denial attitudes and behavior in several countries as responses to changes in the new policy and completely uncertain situations (Alsubaie et al., 2020; Miller, 2020). Denial attitudes and behavior were also found in Indonesia, where a lot of misinformation occurred, and influencing people's attitudes during pandemics (Nasir, Bauequni, \& Nurmansyah, 2020). In the early days of the pandemic, the dynamics of the Indonesian government's policies were classified as ambiguous, and there was a lack of clarity in their direction in responding to the potential crisis that was happening (Widaningrum \& Mas'udi, 2020). There is a tendency to overconfidence and a tendency to neglect that contributed to the current policy crisis. Instead of developing an anticipatory system, the government's response, as illustrated in various statements from the President, Ministers, and other officials, has ignored the potential threat of COVID-19. In terms of subsequent responses, the denial attitude and behavior can be found as responses from all social classes within the lower classes of society and government officials, as explained above (Widaningrum \& Mas'udi, 2020). Previous studies also highlighted that people tend to be afraid only if they or their families become victims of the virus (Lau, Griffiths, Choi, \& Tsui, 2009; Wong \& Sam, 2011).

Furthermore, the circulation of misinformation, massive hoaxes, and conspiracy theories in the community was one of the reasons that stimulated the public to not believe in COVID-19. Misinformation is defined as a false claim related to health without sufficient scientific evidence (Chou, Oh, \& Klein, 2018). It is important to note that misinformation can result in significant short-term or long-term outcomes (Tran, Valecha, Rad, \& Rao, 2020) and stimulate harmful health consequences (Barua, Barua, Aktar, Kabir, \& Li, 2020). Particularly conspiracy theories regarding COVID-19 were developed within the social milieu, including the manufacture behind COVID-19, population reducing agenda, and new world order implementation (Imhoff \& Lamberty, 2020). Douglas, Sutton, and Cichocka (2017) revealed that some individuals are interested in conspiracy theories to fulfill their psychological satisfaction regarding the power of facts, autonomy over one's welfare, and feelings of control. However, the denial caused by believing in conspiracy theories will not last long because it fails to fulfill these psychological needs and basically worsens the situation by creating fear, anxiety, and helplessness. People who believe in several conspiracy theories also tend to underestimate the danger of the virus; thus, they refuse to follow health protocol (physical distancing, hygiene procedure) from the institution they believe as the actor for creating the conspiracy (Imhoff \& Lamberty, 2020).

A previous study by Alsubaie et al. (2020) explained the denial attitude possessed by the majority of Saudi Arabian citizens. Their study highlighted the demographic factors associated with a high denial attitude, including a low level of education, specific age categories (primarily elderly), being married, and occupation in the non-medical sector. Lavorga and Myles (2021) studied how individual and social factors related to science denial mechanism, which was analyzed using social learning theory. Furthermore, Miller (2020) found science denial and maintaining false beliefs were produced by low-level literacy on science. Buguzi (2021) also explained how the denial attitude from the Tanzania government cost many lives. In their study, Cabral, Ito, and Pongeluppe (2021) described 
the effect of the Brazilian President's speech in denying the COVID-19 virus on citizens' risk behavior. Denial attitude possessed and expressed by national figures result in the increasing number of death as public behavior was affected by the narration to ignore health protocol.

Denial attitude and behavior have begun to appear in public spaces, both at national and international levels. Baron and Branscombre (2012) described the attitude as individual evaluation on various aspects of social environment obtained from others through social learning. Social learning is how individuals adopt new information, forms of behavior, or attitudes from others through classical conditioning, instrumental conditioning, or observational learning (Baron \& Branscombre, 2012).

Baron and Branscombre (2012) then further described through observational learning that individuals usually adapt their attitude to become similar with their reference groups, while these groups refer to individuals whose behavior and opinions are considered important. Attitude influences behavior in two mechanisms (Baron \& Branscombre, 2012). The first mechanism occurs when individuals carefully plan and think about their attitude. In this mechanism, behavior can be predicted from the individual intention based on the attitude, the social norm that individuals hold on to, and perceived individual control over behaviors. The second mechanism occurs when an individual does not think about their attitude carefully and deliberately. In this mechanism, attitude is activated in an automatic way or unplanned manner, and then this automatic attitude forms behavior through developing perception of the situation that individual faced.

This attitude and behavior within the public sphere created its complex dynamics as previously described. Thus it is undoubtedly essential to be examined more deeply. The effects of denial attitude and behavior during the pandemic have also had even more counterproductive consequences for society in general and individuals who deny it in particular. Therefore, a study exploring why some people do not believe in the COVID-19 virus and refuse implementation of the health protocol is needed. This paper focused on exploring denial attitude and behavior during the COVID-19 pandemic using a qualitative survey method among those who do not believe in the existence of the COVID-19. The analysis used in this study comes from a scientific psychological perspective, particularly in the framework of seeing attitude and behavior from social psychology and social learning theories.

\section{Method}

This study used a qualitative survey method with open-ended questions, therefore explore diversity in population with no restrictions for the empirical cycle and methods coding (Jansen, 2010). This study focuses on determining diversity about the COVID-19 pandemic topics to develop the variation of meaning based on relevant values and dimensions in the targeted population (Boyatzis, 1998).

\section{Participants}

Fifteen informants have completed the survey and answered the open-ended questions related to the COVID-19 pandemic and the personal belief and perception on pandemic through Google form. The informants are varied on the educational background (high school, vocational school, undergraduate degree, graduate degree), gender (male, female), and age (18-34 years old).

\section{Procedures}

The purposive sampling method was applied to gather participants of the study. The sampling characteristic was individuals who believe the COVID-19 pandemic is part of conspiracy theory or does not exist. Participants gave informed consent through an online 
survey before answering the pre-screening survey and open-ended questions with Google Form. Individuals who passed the criteria by answering "yes" to an online pre-screening question, "Do you believe the COVID-19 pandemic is part of conspiracy theory or does not exist?" were given the main questionnaire containing eleven open-ended questions. The eleven open-ended questions are related to the belief toward COVID-19:

1. Why do you think COVID-19 doesn't actually exist?

2. Why do you think COVID-19 is a conspiracy theory?

3. What do you think about the assumption that COVID-19 is a political conspiracy to weaken certain governments?

4. What do you think about the news of the increase in patients and victims of COVID19 ? Is that a conspiracy too?

5. Has anyone you know been diagnosed with COVID-19? If so, who are they?

6. What do you think about the current conditions regarding the COVID-19 pandemic and its consequences for daily activities, politics, social, education, and economic sectors?

7. How do you actually feel when you see the news about COVID-19?

8. Which information do you often get, and which access do you rely on, related to news about the COVID-19 pandemic?

9. Do you think people around you believe or not believe COVID-19 is real? Who doesn't believe that COVID-19 is real and who believes that COVID-19 is real in your surroundings?

10. How do you view hospitals and healthcare workers who work on the front line to help COVID-19 patients?

11. What do you think about government figures and public figures who said that COVID19 is nothing to worry about or COVID-19 is a conspiracy? Do you agree or disagree? Why?

\section{Data Analysis}

The collected data from 15 participants were then analyzed using several general analysis steps and specific strategies concerning the theory of Creswell (2014). The steps include processing and preparing data, scanning material and initial reading of information, building a general sense of the information obtained, data coding, detailed description of the code, code thematic analysis, and interpretation. Furthermore, the intended interpretation was carried out based on attitude, behavior, and social learning theories.

\section{Results}

The results of this study are divided into two main findings. The first main finding was related to the manifestation of denial attitude and behavior among participants in several forms, such as having a negative perception of healthcare workers and hospitals, believing conspiracy theories, and hating the COVID-19 news from mass media. The second main finding is related to the development of denial attitude and behavior among participants. The denial attitude was basically developed through social and observational learning due to insufficient credible information sources.

\section{The manifestation of denial attitude and behavior}

Believe in conspiracy theories. Participants have denied the existence of the COVID-19 virus. Of 15 participants, all of them did not believe that the COVID-19 pandemic exists as well as the virus itself. More specifically, 7 participants did not believe it because they believed that the COVID-19 is a conspiracy theory made by the global elite who want to destroy certain countries. They believed that the superpowers raised the COVID-19 to destroy the economic order in many countries; hence the majority of countries will enter into the new system. "I don't believe COVID-19 exists because it's a globalist conspiracy. It 
was made by the superpower. Yes, they aim to weaken the world economy so that a handful of people/groups will pretend to help countries in the world with loans. When poor countries can't return it, those few will push those countries to follow their rules. They want to create a single currency and one order of government around the world for their benefit."(S1).

Current feelings due to the COVID-19 pandemic. Those who believe in conspiracy theories explained that they are disgusted and angry about the pandemic because all activities were hampered. "I feel bad, emotional, disgusted by this conspiracy."(S1). They were not afraid of the threat of the COVID-19 virus because the virus did not exist, and even if it exists, they will not give up to fight conspiracy and agenda makers. The coverage in the media is only intended to weaken the economy and stop all social and economic activities. They also specifically described their dislike of the media, which continuously reported on the COVID-19 pandemic. "I am mad at this situation, especially to the agenda makers. I don't like those media who spread the news about how dangerous the COVID-19 virus is. " $(S 3)$

Health protocols during the COVID-19 pandemic. They were wearing masks even though they did not believe in the existence of the COVID-19 virus. They were wearing masks to respect general rules and simply follow recommendations. "I wear the mask, but I am not afraid of the COVID-19 virus." (S5)

Negative perception and reaction towards hospitals and healthcare workers. Several participants believed healthcare workers and systems developed fraud and deception. Specifically, 8 participants believed medical workers and hospitals developed fraud and deception on their diagnosis based on information from surrounding and broadcast messages as well as social media they followed. They believed that the victims who died were not because of the COVID-19 virus but because of the hospital's fraud and deception.

"I don't believe COVID-19 exists because I discussed with a friend ... and the fact that a lot of patients who actually died not because of COVID-19 virus but claimed as COVID-19 patients."(S8.)

They explained that in terms of their knowledge and belief, they knew that the victims who were reported as died from COVID-19 were actually not true and not valid; instead, they believed that those who claimed by hospitals as died from COVID-19 were actually had a history of other diseases. The other diseases were the real cause of death, according to their belief. "It could be. Many facts that people who already suffer from congenital diseases such as tuberculosis, heart disease, diabetes, and complications are finally diagnosed as COVID-19 patients. If they refuse it, they will be asked to pay 15 million by the hospital."(S9.)

They also explained their belief that many hospitals have committed fraud by diagnosing many patients as COVID-19 patients despite having other diseases. According to them, the goal of the hospital to do this is to seek economic benefits. "This could have been fabricated. All people admitted to the COVID-19 referral hospital would be tested, and the results were reactive. If there is a patient with a positive test result, the hospital will receive a fee from the government." (S11)

All participants also expressed their tendency to have negative perceptions of healthcare workers (doctors and nurses). The majority of them had thought that healthcare workers benefited from the pandemic situation. "I don't care of them, and they got money from it."(S12). Other participants felt pity for healthcare workers because they were slaves to conspiracy makers. "The medical workers are the slaves for the conspiracy makers."(S10) 
Fifteen participants who believe conspiracy and who believe the COVID-19 virus does not exist shared the same negative perception or pity on health care workers. Most participants believe the need to blame the global elite and healthcare workers as the actors who created the pandemic to gain economic benefit.

\section{The development of denial attitude and behavior}

Regarding the second main finding on the development of denial attitude and behavior through social learning and observational learning, participants indicated how other people, figures, and the surrounding situation became the factors that affected their current attitude towards COVID-19.

People within participants' social circle. The majority of participants explained that their family, relatives, and other people around them do not believe the COVID-19. "No one believes it. All members of my family from father, mother, sister, uncle, aunt to cousin are not affected by anything related to COVID-19." (S8). However, some participants described people within their social milieu who still believe that the COVID-19 virus was real. "People around me believe in the existence of COVID-19, but we never follow the news, we never sure about the news out there."(S14)

The government and public figures. Most participants agreed with government figures and public figures' statements in favor of the COVID-19 conspiracy theories, including advising not to worry about the COVID-19. "I just agree with them, and I think it will make the mental health of Indonesians better, who have been previously haunted by the dangers of the COVID-19." (S10)

They also respect the former Minister of Health in responding to the bird flu pandemic. "I really appreciate it if you dare to speak up. Especially if you dare to act like the former Minister of Health, Mrs. Siti Fadilla, who can solve the bird flu pandemic not using vaccine but using politics. "(S2)

The source of information the participants accessed during this pandemic. Most participants explained that they received related information according to their belief through several online websites, Youtube, news portals and social media, and broadcast messages. "Youtube, and notifications from the browser that often appear but I never open it." (S13). However, they did not mention that they followed official sources such as the official WHO website, the official COVID-19 handling task force website, and other official sources. "I rarely see the news because these conspiracy makers control most media." (S3). They further explained that they particularly received information from social media status and social media broadcast messages. "I followed online media, social media and WhatsApp group."(S10).

\section{Discussion}

The majority of participants in this study expressed their attitude toward not believing the COVID-19 virus as they evaluated the pandemic situation. Their attitude was favoring conspiracy theories and negatively perceiving healthcare workers was developed through the social learning process. Ajzen (1993) described the attitude as personal disposition and response toward an event, object, person, behavior, and institution. Although the definition of attitude varies, the main characteristics of attitude are the evaluation of both positive and negative on an event, person, or object. Furthermore, Ajzen (2001) also explained that attitude has several components, namely cognitive, affective, and behavioral. The last component here, the behavioral component, is central to understanding the relationship between attitude and behavior. People adopt new information from several sources such as 
people in their inner circle, broadcast messages, and social media they followed. In the social learning process, people also adapt attitudes from others. Many participants stated that they have the same perception as public and government figures who said COVID-19 was not dangerous; the public should not worry about and in favor of conspiracy theories. As Baron and Branscombre (2012) explained, social learning is the process by which individuals adopt new information, forms of behavior, or attitudes from others. Subsequently, through observing others' behavior, individuals also obtain and develop new behaviors. In this context, hearing the reference group or other people in their inner circle declare their views about a particular issue can lead individuals to adopt similar attitudes.

Lyons and Berge (2012) also described that individuals could learn through observing and imitating other behaviors. In this context, the individual learning process consists of social observation and subsequent imitation of attitude and behavior. These theories can explain how most participants do not believe in COVID-19 as many of their family, friends, and relatives also have the same attitude and behavior. They observed other people within their circle and received reinforcement from public figures and government figures when those figures declared their opinion on COVID-19 and received support as a reward. Grusec (1992) explained reinforcement (observation of reward and punishment) is the aspect that can strengthen observational learning. This explanation aligns with Baron and Branscombre (2012), who described individuals usually adapt their attitude to become similar to their reference groups, while these groups refer to individuals whose behavior and opinions are considered essential.

Some participants also indicated that they lacked credible information. Moreover, they believed medical workers and hospitals developed fraud and deception on their diagnosis based on information from the surrounding, including discussion with friends and broadcast messages or social media they followed. It is according to what Ghaemi (2020) explained about the second group of denials with low literacy levels due to their limited access to information related to the COVID-19 pandemic. They have a very skeptical perspective on science, possibly because they do not have access to credible and adequate information about COVID-19.

Furthermore, analysis was made related to the denial as attitude in response to the pandemic. Understandably, the pandemic situation made most participants feel anxious, angry, emotional, and threatened due to the uncertainty and dynamics of ongoing COVID19 pandemic news and information they received from mass media. Ritchie (2014) explained that the modern conceptualization of denial is when individuals refuse to accept threatening information as a fact (evidence), whether real or imaginary. In a psychological context, denial includes several ways for a person to protect themself from several imagined and real threats. When an individual experiences a threat, denying the threat can give the person time to assess the meaning and severity before reacting.

The majority of participants in this study did not believe in the COVID-19 virus and disliked any information related to the COVID-19 pandemic provided by mass media and official World Health Organizations because they felt that news and information are threatening, particularly for their economics activities. They had insufficient credible sources of information as they could not differentiate between credible sources and those that are not. They also explained in their answers that they felt overwhelmed, angry, helpless, and disappointed because of the pandemic. Rudenstine and Galea (2014) explained five general reaction phases to disasters. The first phase is self-preservation, where the initial reaction appeared in the form of fear and anxiety. Then the second phase is group preservation, which is the phase when the required information has been obtained. The individual tends to develop pro-social behavior to help other individuals. Furthermore, the third phase is called the blame setting. The individual begins to go through a process of internalization and experiences psychological consequences. In this stage, the individuals feel emotional responses related to changes in normal activities. When identifying 
emotional responses, individuals also begin to identify who is to blame. Then individuals will also try to identify the vulnerabilities, weaknesses, and strengths that are owned and felt during a disaster/threatening situation. The fourth phase is justice-seeking, which is an externalization process in which individuals seek compensation and lead to take action against actors who are considered to be blamed. Then the last phase is called renormalizing, where individuals and groups can fully adapt to disasters or situations that contain threats. Based on this theory, it can be concluded that participants who felt frustrated in handling the changes during the pandemic experienced the third phase of the reaction.

In the context of reaction to the pandemic through denial versus panic perspective, this study shows that the participants' reactions were not panic but denial. Denial becomes more common than panic as a reaction during a pandemic. In this regard, denial appeared similar to apathy. People with denial are unwilling to give their attention and awareness to the issue (Sandman, 2002). Denial can also be described as a natural way to protect themselves from the harmful effects of feeling panic (Sandman, 2014).

Based on Rudenstine and Galea (2014), the denial attitude and behavior can be identified as reactions on the third and fourth phases of five general reaction phases to disasters. The third phase is called the blame setting, in which individuals begin to go through a process of internalization and experienced psychological consequences. They felt emotional responses related to changes in normal activities. When identifying emotional responses, they also begin to identify who is to blame. Then individuals will also try to identify the vulnerabilities, weaknesses, and strengths that are owned and felt during a disaster/threatening situation. However, several factors, including lack of access to credible information and the spread of conspiracy theory, could affect how participants identify which information they need to believe, finally, how they identify who is to blame. In the fourth phase, which is described as justice-seeking, an externalization process occurs. Individuals seek compensation and lead to action against actors who are considered to be blamed. Most participants believe the need to blame the global elite and healthcare workers as the actors who created the pandemic to gain economic benefit.

This study has several limitations. In the context of each participant's answer, this study has limited exploration on a deeper level. Because the questions and answers were conducted through an online survey due to the pandemic that made it impossible to meet in person, researchers could only study each participant's answers through the qualitative survey method with open-ended questions. The study also only could gather participants from the limited demographic background, focused on young adults and adults (18-34). However, all participants represented diverse backgrounds (high school, vocational school, undergraduate degree, and master's degree). These limitations are expected to be improved for future research to obtain the pandemic denial phenomena. Further studies are needed, particularly with a larger population, with more in-depth and diverse explorations by applying a longitudinal approach and mixed method, as the second wave of the pandemic has begun and the individual responses to pandemic appear more diverse.

\section{Conclusion}

From the social learning process perspective, information from the surrounding and broadcast messages through social media cause a denial of the COVID-19 pandemic. Denial attitude and behavior were identified as a response to the COVID-19 pandemic as an unexpected condition. Therefore, individuals look for the party to blame for this uncertain situation by believing in a conspiracy theory and suspect that medical workers and hospitals developed fraud and deception. Observational learning with the existence of a reference group strengthens individuals forming behavior similar to their reference group. When the 
situation is very threatening and an individual cannot cope; thus the tendency in denying the COVID-19 pandemic is very likely to occur.

\section{References}

Ajzen, I. (1993). Attitude theory and the attitude-behavior. In K. Dagmar \& Schmidt, P (eds.). New directions in attitude measurement. Walter de Gruyter.

Ajzen, I. (2001). Nature and operation of attitudes. Annual Review of Psychology, 52, 27 58. https://doi.org/10.1146/annurev.psych.52.1.27

Alsubaie, S., Alshahrani, H., Alshahrani, A., Asiri, A., Alfaifi, A., Al Ibrahim, R., \& Alqahtani, W. (2020). Denial attitude toward COVID-19 among general population in Saudi Arabia. International Journal of Medicine in Developing Countries, 4(12), 2292-2298. https://doi.org/10.24911/IJMDC.51-1605046317

Baron, R. A., \& Branscombre, N. R. (2012). Social psychology $\left(13^{\text {th }}\right.$ ed.). Pearson.

Barua, Z., Barua, S., Aktar, S., Kabir, N., \& Li, M. (2020). Effects of misinformation on COVID-19 individual responses and recommendations for resilience of disastrous consequences of misinformation. Progress in Disaster Science, 8, 100119. https://doi.org/10.1016/j.pdisas.2020.100119

Boyatzis, R. E. (1998). Transforming qualitative information: Thematic analysis and code development. Sage Publications, Inc.

Buguzi, S. (2021). Covid-19: Counting the cost of denial in Tanzania. BMJ (Clinical Research Ed.), 373, n1052. https://doi.org/10.1136/bmj.n1052

Cabral, S., Ito, N., \& Pongeluppe, L. (2021). The disastrous effects of leaders in denial: Evidence from the COVID-19 crisis in Brazil. http://dx.doi.org/10.2139/ssrn.3836147

Chou, W. S., Oh, A., \& Klein, W. (2018). Addressing health-related misinformation on social media. JAMA, 320(23), 2417-2418. https://doi.org/10.1001/jama.2018.16865

Creswell, J. W. (2014). Research design: Qualitative, quantitative, and mixed methods approaches. $\left(4^{\text {th }}\right.$ ed.). SAGE Publications Inc.

Djalante, R., Lassa, J., Setiamarga, D., Sudjatma, A., Indrawan, M., Haryanto, B., ... Warsilah, H. (2020). Review and analysis of current responses to COVID-19 in Indonesia: Period of January to March 2020. Progress in Disaster Science, 6(2020), 100091. https://doi.org/10.1016/j.pdisas.2020.100091

Douglas, K. M., Sutton, R. M., \& Cichocka, A. (2017). The psychology of conspiracy theories. Current Directions in Psychological Science, 26(6), 538-542. https://doi.org/10.1177/0963721417718261

Fadhal, S. (2020). Komunikasi publik di tengah krisis: Tinjauan komunikasi pemerintah dalam tanggap darurat pandemi COVID-19 (Public communications in the midst of a crisis: Overview of government communications in the COVID-19 pandemic emergency response). In D. H. Santoso. Media, komunikasi \& informasi di masa pandemi COVID-19. MBridge Press.

Ghaemi, N. (2020). The psychology of pandemic denial: Why do some people reject the science of public health? Retrieved from https://www.psychologytoday.com/us/blog/mood-swings/202003/the-psychologypandemic-denial

Grusec, J. E. (1992). Social learning theory and developmental psychology: The legacies of Robert Sears and Albert Bandura. Developmental Psychology, 28(5), 776-786. https://doi.org/10.1037/0012-1649.28.5.776

Imhoff, R., \& Lamberty, P. (2020). A bioweapon or a hoax? The link between distinct 
conspiracy beliefs about the coronavirus disease (COVID-19) outbreak and pandemic behavior. Social Psychological and Personality Science, 11(8), 1110-1118. https://doi.org/10.1177/1948550620934692

Jansen, H. (2010). The logic of qualitative survey research and its position in the field of social research methods. Forum Qualitative Sozialforschung / Forum: Qualitative Social Research, 11(2). https://doi.org/10.17169/fqs-11.2.1450

Kawalcovid19. (2020). Jumlah kasus di Indonesia saat ini (Number of cases in Indonesia now). Retrieved from https://kawalcovid19.id/

Lau, J. T., Griffiths, S., Choi, K. C., \& Tsui, H. Y. (2009). Widespread public misconception in the early phase of the H1N1 influenza epidemic. The Journal of Infection, 59(2), 122-127. https://doi.org/10.1016/j.jinf.2009.06.004

Lavorga, A., \& Myles, H. (2021). Science denial and medical misinformation in pandemic times: A psycho-criminological analysis. European Journal of Criminology, online fir, 1-21. https://doi.org/10.1177/1477370820988832

Lyons, S. D., \& Berge, Z. L. (2012). Social Learning Theory. In: Seel N.M. (eds). Encyclopedia of the sciences of learning. https://doi.org/10.1007/978-1-4419-14286_1257

Mahendradhata, Y., Andayani, N., Hasri, E. T., Arifi, M. D., Siahaan, R., Solikha, D. A., \& Ali, P. B. (2021). The capacity of the Indonesian healthcare system to respond to COVID-19. Frontiers in Public Health, 9, 649819. https://doi.org/10.3389/fpubh.2021.649819

Mas'udi, W., \& Winanti, P. S. (2020). COVID-19: Dari krisis kesehatan ke krisis tata kelola (COVID-19: From a health crisis to a governance crisis). In P. S. Winanti \& W. Mas'udi (eds). Tata kelola penanganan COVID-19 di Indonesia. Gadjah Mada University Press.

Miller, B. L. (2020). Science denial and COVID conspiracy theories: Potential neurological mechanisms and possible responses. JAMA, 324(22), 2255-2256. https://doi.org/10.1001/jama.2020.21332

Nasir, N. M., Bauequni, \& Nurmansyah, M. I. (2020). Misinformation related to COVID19 in Indonesia. Jurnal Administrasi Kesehatan Indonesia, 8(Special Issue), 51-59.

Paramadhita, A. (2021). PPKM Darurat necessary for sustainable recovery in Indonesia. The Jakarta Post. Retrieved from https://www.thejakartapost.com/news/2021/07/06/ppkm-darurat-necessary-forsustainable-recovery-in-indonesia.html

Ritchie, T. D. (2014). Denial. In T. R. Levine (ed.). Encyclopedia of lying and deception. Sage Publications Inc.

Rudenstine, S., \& Galea, S. (2014). Behavioral consequences of disasters: A five-stage model of population behavior. Disaster Medicine and Public Health Preparedness, 8(6), 497-504. https://doi.org/10.1017/dmp.2014.114

Sandman, P. (2002). Beyond panic prevention: Addressing emotion in emergency communication. Emergency Risk Communication CDCynergy (CD-ROM) Centers for Disease Control and Prevention, U.S. Department of Health and Human Services. Retrieved from http://www.psandman.com/articles/beyond.pdf

Sandman, P. (2014). How do people react in a pandemic? Retrieved from https://nieman.harvard.edu/wpcontent/uploads/podassets/microsites/NiemanGuideTo CoveringPandemicFlu/CrisiCommunication/HowDoPeopleReactInAPandemic.aspx.h tml\#reactions

Tran, T., Valecha, R., Rad, P., \& Rao, H. R. (2020). An investigation of misinformation harms related to social media during two humanitarian crises. Information Systems 
Frontiers, 1-9. Advance online publication. https://doi.org/10.1007/s10796-02010088-3

Utami, B. S., \& Aliyansah, P. I. (2020). COVID-19: Challenges and opportunities in Indonesia health sector. [Paper Presentation]. The 5th International Conference on Energy, Environmental and Information System (ICENIS 2020). Retrieved from https://pesquisa.bvsalud.org/global-literature-on-novel-coronavirus-2019ncov/resource/pt/covidwho-943935

WHO. (2020). WHO coronavirus disease (COVID-19) dashboard. Indonesia situation. Retrieved from https://covid19.who.int/region/searo/country/id

Widaningrum, A., \& Mas'udi, W. (2020). Dinamika respons pemerintah nasional: Krisis kebijakan penanganan COVID-19 (Dynamics of national government response: Policy crisis in handling COVID-19). In P. S. Winanti \& W. Mas'udi (eds). Tata kelola penanganan COVID-19 di Indonesia. Gadjah Mada University Press.

Wong, L. P., \& Sam, I. (2011). Knowledge and attitudes in regard to pandemic influenza $\mathrm{A}(\mathrm{H} 1 \mathrm{~N} 1)$ in a multiethnic community of Malaysia. Int.J. Behav. Med, 18, 112-121. https://doi.org/10.1007/s12529-010-9114-9 